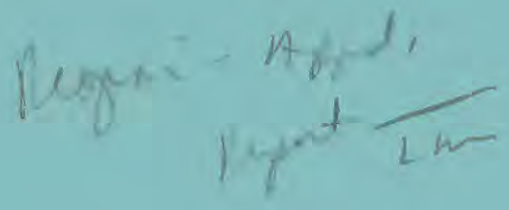

\title{
PHYTOPLANKTON ABUNDANCE AND GENERIC COMPOSITION DATA FOR THE POTOMAC RIVER AND ESTUARY, MARYLAND
}
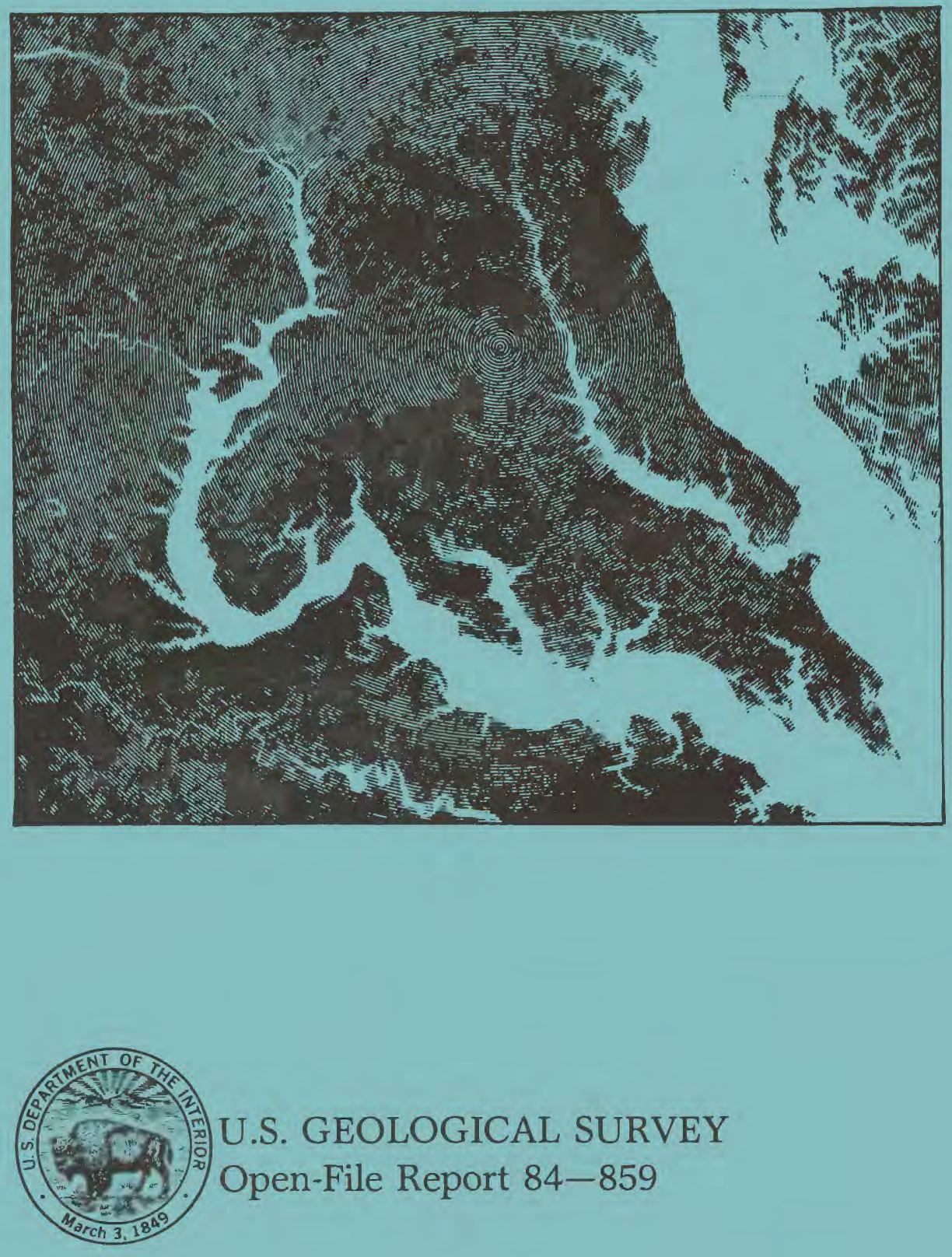


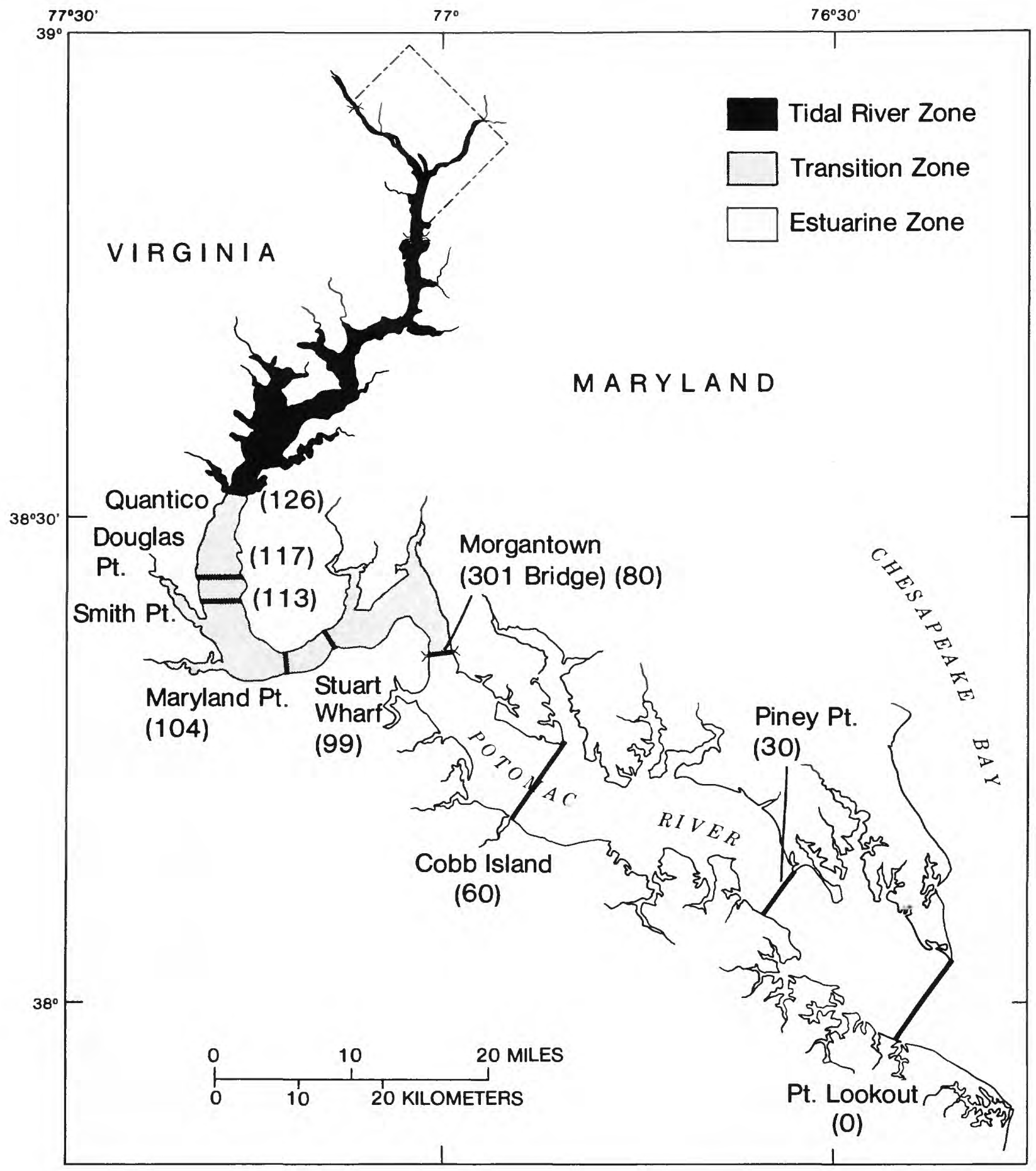

Figure 2b.--Location of sampling stations in the transition zone and Estuary. Sampling station distance, in kilometers from mouth of Potomac, are in parentheses. 


\section{METHODS}

Sampling Stations.--Table 1 lists stations and station numbers at which phytoplankton samples were taken.

Methods for Phytoplankton Cell Counts and Identification

Depth-integrated samples were collected from the water column and 250milliliter of the raw sample were preserved with either Lugol's iodine or Lugol's iodine with acetic acid and transported to the laboratory. The samples were shaken thoroughly before placing 5-milliliter subsamples into 10-milliliter Wild-Heerbrugg $1 /$ settling chambers. The bottom of the chambers were \#1 coverslips. Phytoplankton sampled in 1979, 1980 and January to June 1981 were counted at a magnification of 400 by K. E. Boulukos and V. A. Stoelzel using the Utermohl inverted-microscope method (Utermoh1, 1958; Lund and others, 1958). From 60 to 120 cells in six to ten grids were counted in each sample. On some rare occasions, when phytoplankton abundance was very low, fewer cells were counted and where densities exceeded $5 \times 10^{7}$ cells per liter, fewer than six grids were counted. Phytoplankton sampled in July, August, and September 1981 were counted by a technician at Wapora Inc. $1 /$, and a minimum of 100 cells were counted at 280 magnification. Small (1 to $5 \mathrm{\mu m}$ ) cells in samples counted in our laboratory at Reston, Va. were examined frequently at a magnification of 500-600 to ensure that they were not detritus or bacteria. The technique is similar to that described by Greeson and others (1979) and Hasle (1978).

$1 /$ The use of brand names in this report is for identification purposes and does not constitute endorsement by the U.S. Geological Survey 
Table 1.--A list stations at which phytoplankton were sampled. The stations are marked on figure 2 .

Station Number Listed in WATSTORE

01646580

385315077031800

385315077022400

385223077012600

384852077020500

01652590

384605077015800

384318077020300

384136077054600

383818077072800

01655480

01658710

382640077159900

382233077102000

01660800

381516076503000

01661475

380212076195000
Station Name stated as Potomac River at:
River distance from Chesapeake Bay in kilometers
Chain Bridge, Washington, D.C.

187.2

Memorial Bridge, Washington, D.C.

179.5

14th Street Bridge, Washington, D.C.

Geisboro Point, Washington, D.C.

Marbury Point, Washington, D.C.

Alexandria, Virginia

Rosier Bluff, Maryland

Hatton Point, Maryland

Marshall Ha11, Maryland

Hallowing Point, Virginia

Indian Head, Maryland

Quantico, Virginia

Douglas Point, Maryland

Stuart Wharf, Virginia

Morgantown, Maryland

Cobb Island, Maryland

Piney Point, Maryland

Pt. Lookout, Maryland
177.3

173.7

170.4

168.0

165.6

160.0

151.0

144.0

138.9

125.6

116.7

98.9

80.4

60.0

29.8

6.5 
The primary, general references used for identification of genera were Prescott (1978), Campbell (1973), Whitford and Schumacher (1973), Wood and Lutes (1967), and Prescott (1962). A secondary general reference was Butcher (1959). References for the identification of particular classes of phytoplankton are as follows: Cocke (1967) for the coccoid blue-green algae; Drouet and Daily (1956) for the coccoid myxophyceae; Hustedt (1930) for the centric diatoms; Patrick and Reimer (1966, 1975) for diatoms; Prescott (1962 and 1978) for euglenoids, flagellated green algae and filamentous bluegreens; Hulbert (1965) for brackish water flagellates; and Saunders and Glenn (1969) for diatoms. When identification was uncertain, photographs were taken or drawings were made at the microscope and were occasionally brought to local phycologists at Georgetown University (Phillip Sxe) and the Smithsonian Institution for consultation.

Phytoplankton identifications, cell counts, station, date and time were entered into a computer file called the Biological File, which is an adjunct of WATSTORE, (the U.S. Geological Survey National Water Data Storage and Retreival System). Each phytoplankton taxa is entered as an identification code obtained from a list supplied by the Atlanta Laboratory of the U.S. Geological Survey. Due to name changes, differences and disagreement in the taxonomy literature, uncertainties of genera identification and presence of unknown organisms, special classifications were set up in the Biological File. The description or names of the organisms and corresponding Biological File classification are presented in table 2. Phytoplankton that frequently were observed in the Potomac River and Estuary and previously were not part of the Biological File were issued new identification numbers. These phytoplankton and their identification numbers are listed in table 3 . 
Table 2.--Differences between classification schemes used by the Potomac Estuary Study Project and those of the U.S. Geological Survey Biological File.

\section{Identification}

coccoid green

unknown green

unknown algae

unknown flagellate

unknown diatom

unknown blue-green

unknown dinoflagellate

unknown desmid

unknown yellow-green

unknown cyst

dinoflagellate cyst

zoospore

epiphyte

Chlamdydomonas

Merismopedia

Katodinium

Aphanocapsa

Ebria tripartita

Gleothece

Marssoniella

Amphiprora

Holopedium

Protococcus

Mallomonops is

Chroococcus

Lagerhemia

Aphanothece

Pseudoanabaena

Chlorella

Tribonema
As 1 isted

on Biological File

Chlorococcales

Chlorophyceae

unknown 200000000000000

Euglenophyta

Bacillariophycaea

Cyanophyceae

Dinophyceae

Desmidiaceae

Xanthophyceae

Unknown 200000000000000

Dinophyceae

Euglenophyta

Xanthophyceae

Chlorococcales

Agmenel lum

Massartia

Anacystis

Ebriales*

Coccochloris

Gomphosphaeria

Entomoneis

Agmel lum

Desmococcus

Chrysophyceae

Chroococcaceae

Chodatella

Coccochloris

Oscillatoria

Chlorococcales

Rhizoselenia

*Given an order classification by the U.S. Geological Survey Atlanta Laboratory. 
Table 3.--New identification numbers added to the Atlanta Labs list of organisms.

\begin{tabular}{lllllll}
\hline Hymenomonas & 216 & 02 & 08 & 01 & 002 & 000 \\
Pseudopedinella & 216 & 02 & 01 & 13 & 001 & 000 \\
Tetraselmis & 211 & 01 & 01 & 09 & 001 & 000 \\
Heterocapsa & 215 & 02 & 01 & 03 & 002 & 000 \\
Cladopyxis & 215 & 02 & 01 & 08 & 001 & 000 \\
Polykrikos & 215 & 02 & 01 & 10 & 001 & 000 \\
Sennia & 213 & 01 & 01 & 04 & 001 & 000 \\
Ptychodiscus & 215 & 02 & 01 & 09 & 001 & 000 \\
Dicellula & 211 & 01 & 09 & 10 & 014 & 000 \\
Pseudostaurastrum & 216 & 01 & 02 & 01 & 014 & 000 \\
Pseudotetraedron & 216 & 01 & 02 & 03 & 008 & 000 \\
& & & & & & \\
\hline
\end{tabular}


The following is a list of additional notes concerning taxonomy:

1. The diatom Cyclotella was identified only if marginal costae were visible, otherwise they were considered Stephanodiscus;

2. Wapora reported the genera Platymonas where Stoelzel and Boulukos reported Tetraselmis. The genera are synonomous. Wapora reported observing Westella. Westella was not seen by the Reston laboratory. In all other cases, Wapora reported no other organisms that were not seen also by the Reston laboratory:

3. Chroococcus and Anacystis, both members of the Order Chroococcales, were present in July and August 1980 samples. In some samples of that period, Chroococcus was undifferentiatable from Anacystis and was classified as Anacystis in the Biological File.

4. Stephanodiscus decreased in number at the transition zone and increased again in the estuary. Therefore, they may have been different species.

5. In one case, we were uncertain about the identification of a filamentous colony. It was initially identified as Ulothrix, a green algae, due to the shape and color of the parietal chloroplasts. The organism resembled Melosira, a centric diatom, but did not survive standard tests to identify the siliceous cell wall (Hasle, 1978). The cells did not survive burnt slide preparations. The cells dissolved upon treatment with acid. They lacked the spines that are typical of Melosira. Initial cultures of the organisms by Boulukos were green but became brown when settled out for identification. Photographs of cultures, however have revealed spines. We have 
concluded, with the help of Phillip Sxe (personal commun. 1982), that the organism is a weakly siliceous form of Melosira. Wherever Ulothrix appears in the tables, it should be considered the diatom Melosira.

There are several procedural steps involved in counting and identifying phytoplankton. Each step is a source of variability. First, a sample has to be taken from a time and space variable system. For example, when one sample a week was taken during the first two weeks of July 1980 at the Alexandria station, cell counts were 18000 cells per milliliter the first week and 60000 cells per millimeter the second week. When 11 and 6 samples were taken the week of July 23 and July 30, 1980, respectively, the weekly averages, were 12,464 and 11,733 . Thus, a high system variance was averaged out by taking many samples.

Second, a 250-milliliter subsample is taken from the original sample and is fixed with Lugol's solution. A 5-milliliter subsample is placed in a counting chamber and several grid areas are selected for counting (the grid is a subsample of the bottom area of the chamber). One to ten grids are required to observe all species when cell densities are greater than $2 \times$ $10^{5}$ cells per liter (Eloranta, 1978).

The limits of error due to sampling can be calculated as

$$
\text { error } \max = \pm 2 \cdot\left(\frac{100}{\sqrt{n}}\right) \text { percent }
$$

(with 95 percent confidence) where $n$ is the number of cells counted (Eloranta, 1978). The number of organisms counted per sample in the Reston and Wapora laboratories almost always was between 60 and 120, yielding a maximum sampling error for any sample of between \pm 25 and 20 percent, with 
95 percent confidence. The precision of replicated counts performed by Stoelzel was \pm 10 percent of the mean and was less than the theoretical error due to sampling. Lund states (Lund and others, 1958) that, if replicate counts by an individual yield a variation that is less than the theoretically determined error inherent in random sampling, the personal counting error can be ignored. Therefore, the confidence limits based on theoretical random sampling error ( \pm 20 to 25 percent) can be used as a measure of an individual's counting precision. It is rarely necessary to count more than 100 cells because the accuracy of the count varies inversely with the square root of the number counted (Frontier, 1972; Venrick, 1978). Thus, we would have had to count 400 cells per sample to increase the random sampling error to \pm 10 percent. The Potomac River and Estuary were not dominated by large colonies of algae in 1980 and 1981 . If colonies were present in large numbers, counting variability would be expected to be much higher.

We tested counting precision by performing two double-blind experiments using samples taken at the same time and place and treated the same way. In the double blind test, the counter did not know that the test was taking place and the testor did not organize the samples to be tested. In the first test, five samples counted had a mean of 14,958 cells per milliliter and a standard deviation (S.D.) of 1,566 cells per milliliter. For comparison, the five samples had a mean chlorophyll-a of 60.5 micrograms per liter with an S.D. of 9.6 micrograms per liter. The second test with four samples yielded a mean of 20,588 cells per milligrams and an S. D. of 2,122 cells per milliliter. The chlorophyll-a mean was 117 micrograms per 1iter, with an S.D. of 13.9 micrograms per liter. Zero-blind tests yielded singleperson precision estimates with 2 to 5 percent error. 
Personal counting error for any individual counter may be insignificant compared to sampling error. However, as reported by Lund and others (1958) and Hobro and Willen (1977), counts by more than one observer or laboratory may differ significantly.

Stoelzel performed nearly 80 percent of the counts done by the Reston laboratory and over two-thirds of all the counts. Therefore, Stoelzel counts were used as a standard to which other counters could be compared. Five percent of the samples counted by Wapora were subsampled and counted by Stoelzel and Boulukos. Regressions were performed such that Boulukos' and Wapora's counts could be converted to counts comparable to Stoelzel's. A non-linear equation, $y=A \cdot X^{B}$, fit the data well (fig. 3 ). The data, however, demonstrated heteroscedasticity. Therefore, linear regressions were done in logarithmic space: $\ln Y=A+B \ln X$.

Logarithmic tranformation has the property of converting absolute error to proportional error and does not give undue weight to the residuals of large numbers. The logarithmic, least-squares regressions are shown in figure 4. Stoelzel's counts are considered the dependent variable because the model must predict a count that is comparable to those of Stoelzel. Thus, any comparison between July to August 1980 counts and July to August 1981 counts must be corrected by the use of the equations in figures 3 and 4 .

There were occasional, inadvertent duplicates of counts. If the second sample was stored for longer than 6 months, some degradation of the sample was apparent, as demonstrated by a decrease in the cell count. In 41 percent of the cases there was little or no change in the counts. Cell numbers decreased in 38 percent and increased in 21 percent of the cases. The increase can come about due to clumping of degrading cells and resulting non-random distribution. 


\section{PHYTOPLANKTON ABUNDANCE AND GENERIC COMPOSITION DATA FOR THE POTOMAC RIVER AND ESTUARY, MARYLAND}

by R.R.H. Cohen, S.O. Pollock, V.E. Stoelzel and K.E. Boulukos 

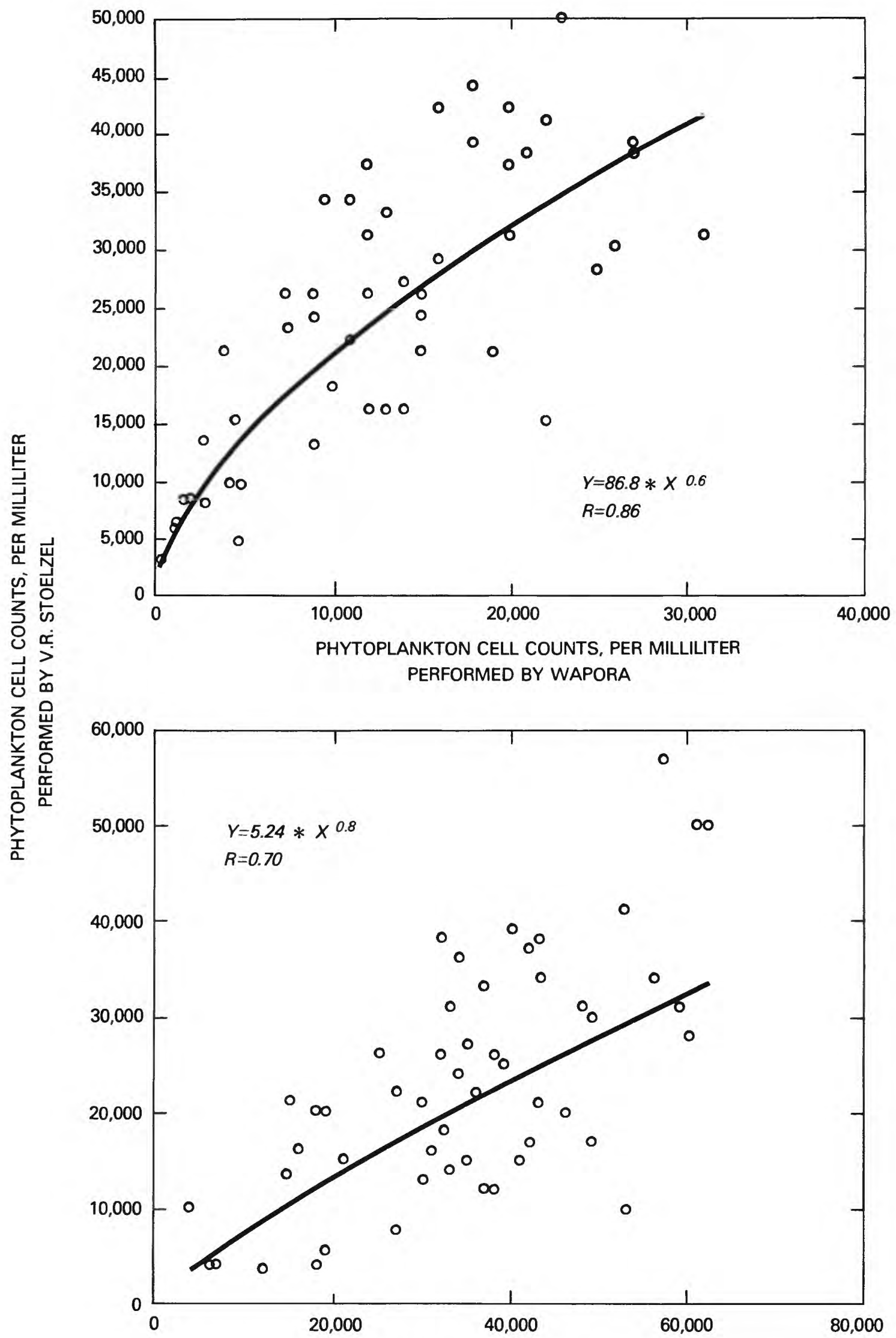

PHYTOPLANKTON CELL COUNTS, PER MILLILITER

PERFORMED BY K.E. BOULUKOS

Figure 3.--Least squares regression of counts performed by Boulukos and Wapora to counts performed by Stoelzel 

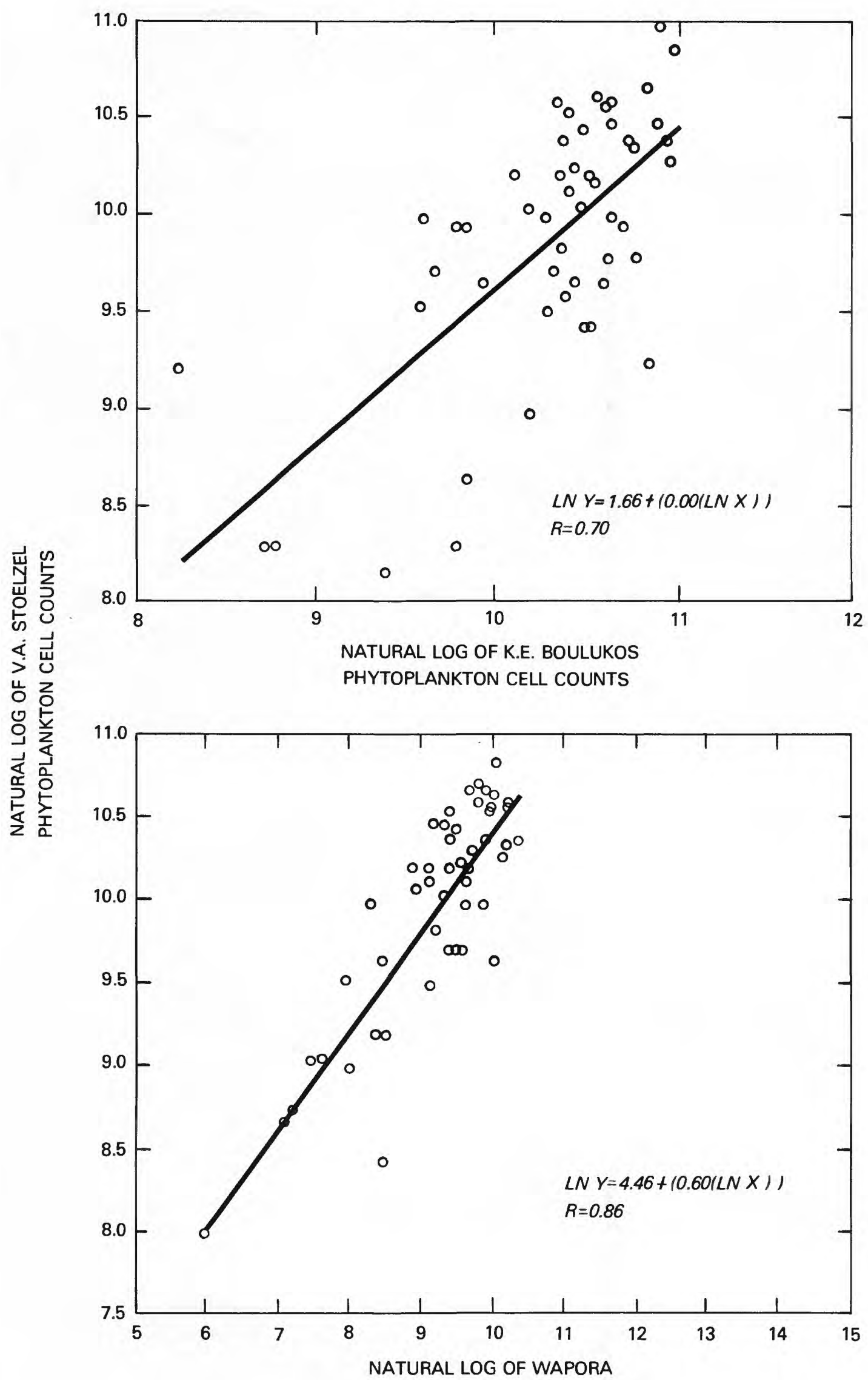

PHYTOPLANKTON CELL COUNTS

Figure 4.--Natural logarithm regressions of counts performed by Boulukos and Wapora to counts performed by Stoelzel. 
If a duplicate count was found, the cell count selected for the original sampling time in the WATSTORE data files was selected using the following priority list.

1. In July and August 1981, Wapora counts were used to be consistant because 95 percent of the counts of that period were performed by Wapora. 2. The identification performed closest to the sampling date was used to reduce the effects of sample degradation.

3. If Stoelzel and Boulukos both counted a sample, those counted by Stoelzel were used because she counted 80 percent of the samples done by the Reston laboratory.

Calibration counts were entered into the Biological File. If Wapora was one of the summer 1981 counters, the sample was labelled with the correct sampling time. Stoelzel's count was labelled with a time that had one minute added. Then, Boulukos' count was given a time with an additional minute added (eg. 1040, 1041, and 1042 respectively). If there was no Wapora count, then Stoelzel's count was given the correct sampling time and Boulukos' count was given a time with one minute added (eg. 1040 and 1041).

It is important that class and generic composition of samples identified by the Reston laboratory and Wapora are comparable. Thirty-two samples that were counted in both laboratories were examined. The dominant class (diatoms, greens, bluegreens and others) as determined as a percent of total cells and the class with the second highest percent of total cells were the same in 28 of 32 cases. In three of the remaining four cases, there was little difference between the percent composition of the top two classes. Only one sample (August 15, 1981, Memorial Bridge) differed dramatically. 
In order to determine how well the class compositions compared between Stoelzel and Wapora, the percent composition of a class as determined by Wapora was subtracted from the percent composition determined by Stoelzel. The absolute value of the difference in percent composition was used for the following calculations. The mean percent difference between Stoelzel and Wapora for all classes combined was 7 percent. The mean diatom, green algae, bluegreen algae, and cryptophyceae percent difference was $13,6,6$, and 4 , respectively.

Wapora's percent diatom composition of samples was, on the average, 29 percent higher than that reported from the Reston laboratory. Reston percen. green algae was ten percent higher than Wapora. The percent composition of cryptophyceae reported by Wapora was five percent higher than that by Reston There was less than one percent average difference between percent composition of bluegreen algae reported by Wapora and Reston.

\section{DATA PRESENTATION}

Table 4 is a full size, representative sample of the phytoplankton cell counts and percent composition by station, date and time that is to be found in the microfiche supplied with this report. 
Table 4. A full size of the microfiche listing of phytoplankton genera. The data are grouped by station (shown on top of the listing) progressing downstream. Within each station, phytoplankton samples are organized by date and time horizontally. The sample data are printed vertically and are continued onto the following pages. Total cells per milliliter for each sample is printed at the top of each column. When there is no notation next to the total cell number the count was performed by $V$. Stoelzel. A greater than sign $(>)$ signifies that the count was performed by WAPORA. A less than sign $(<)$ signifies that the count was performed by $K$. Boulukos. The phytoplankton genera are phylogenetically organized by division, class, order, family and genus. Cells-per-milliliter and percent of the total count are listed for each genus in the sample. Shannon and Weaver's diversity indices are presented at the top of the sample listing by division, class, order, family and genus. \# represents a dominant organism (equal to or greater than 15 percent). Dashes (--) mean that genus was not present in count. Asterisk (*) means that the organism was present but at less than one half of a percent of the total count. Pages are arranged on the microfiche by column from top to bottom and from left to right. 

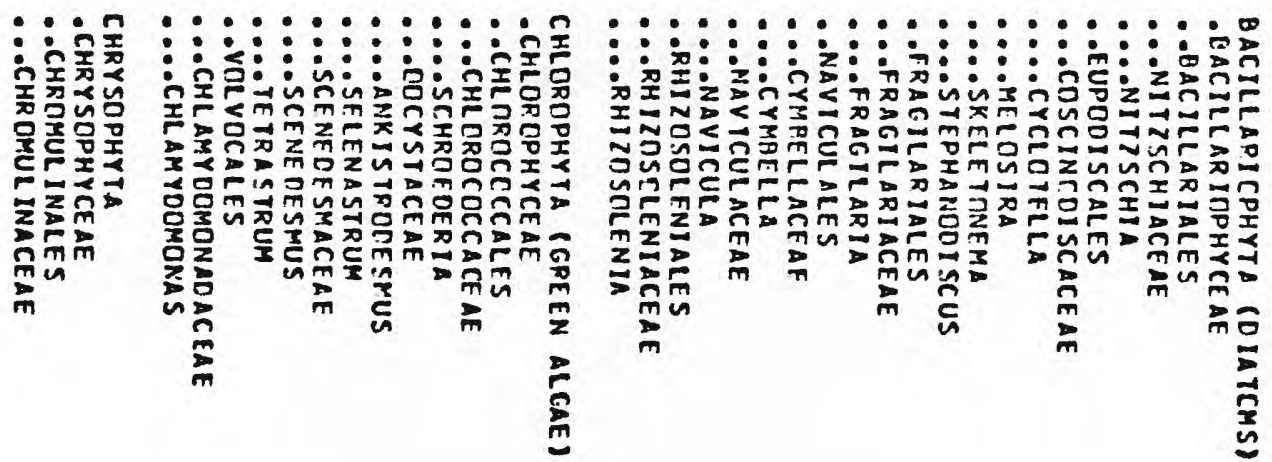

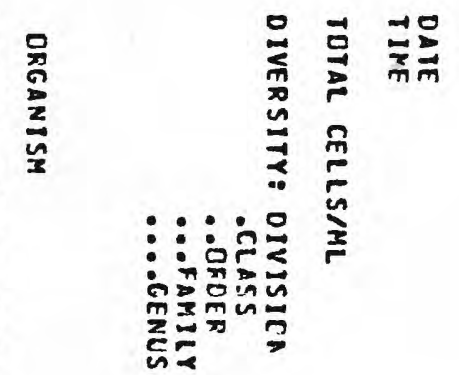

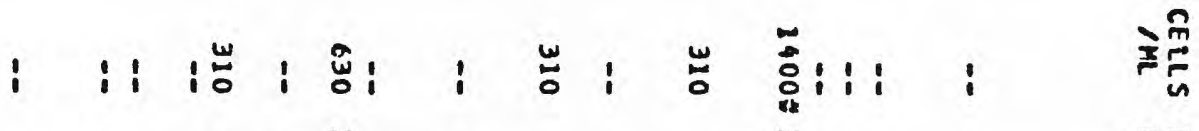

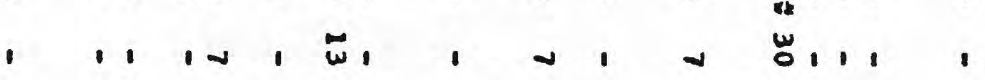

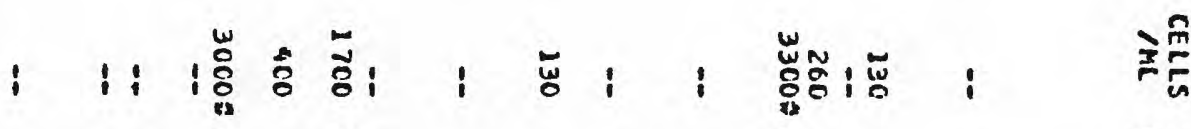

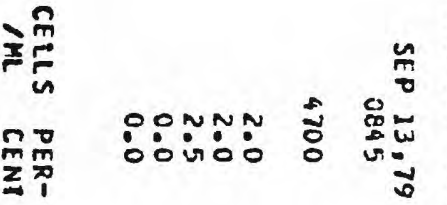

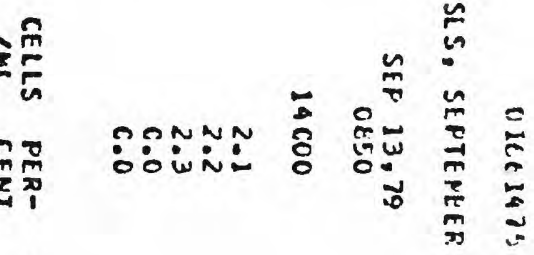

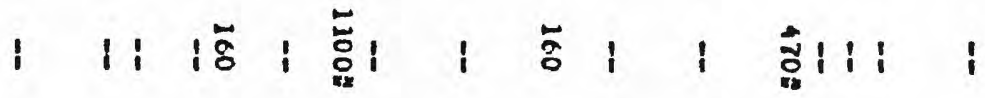

吾皇

$\sim, 1,1$

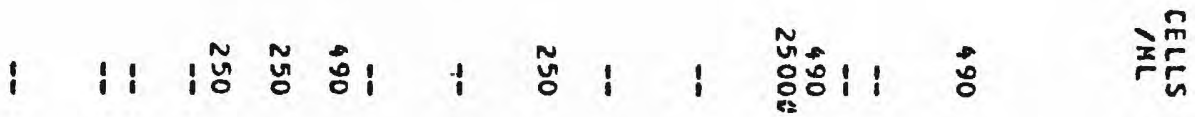

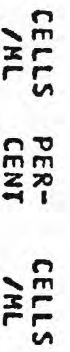

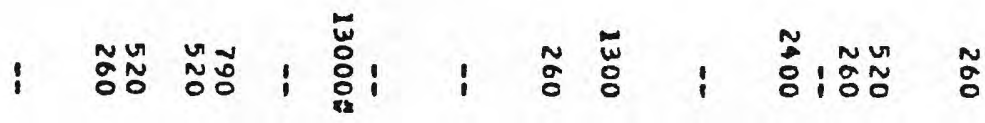

:0n:T :

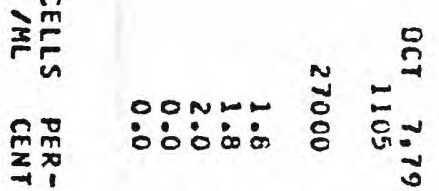

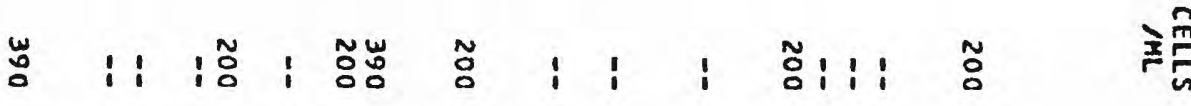

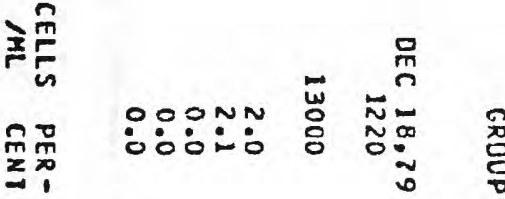

in 

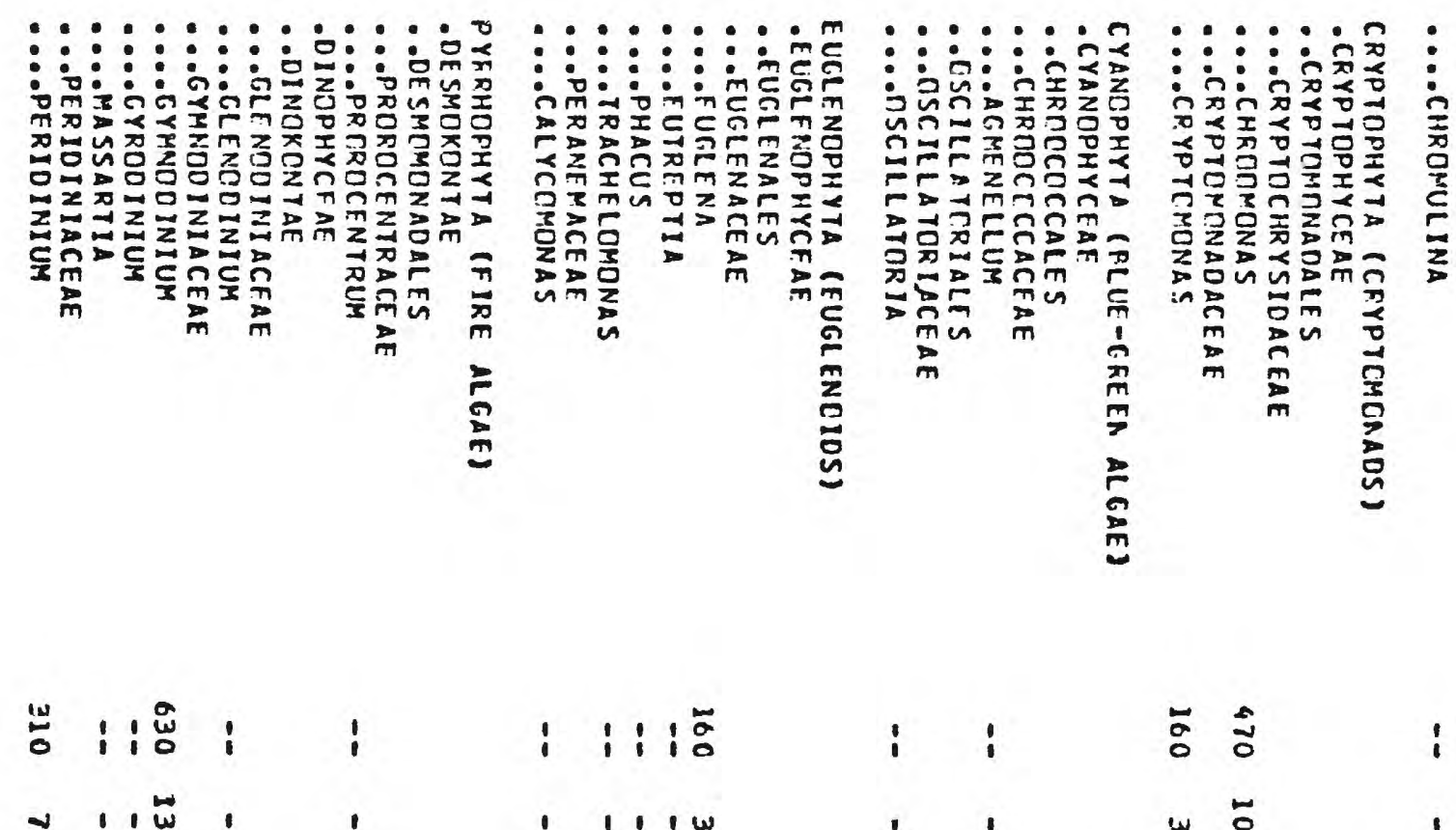

$: 1: i^{5}$

aे

$\checkmark, 1 \omega$

i i i i

i 岕 : i 岁

$\check{\sigma}$

๘

, 1,

| 络! 1 1

$111: 1$

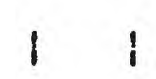

$1 \%$

11211

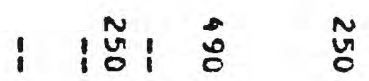

$1: 1: 1$

$\tilde{y} \stackrel{\tilde{O}}{0}$

$\omega \approx$

$\stackrel{0}{0}$

$\sim \infty$

$11012 \omega$

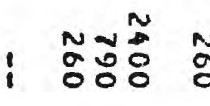

:

$\omega$
0

$\widetilde{\widetilde{\alpha}}$

$1-\omega \sigma$

1

$1 \quad 1-\infty$

$1 \quad n$

N N

1

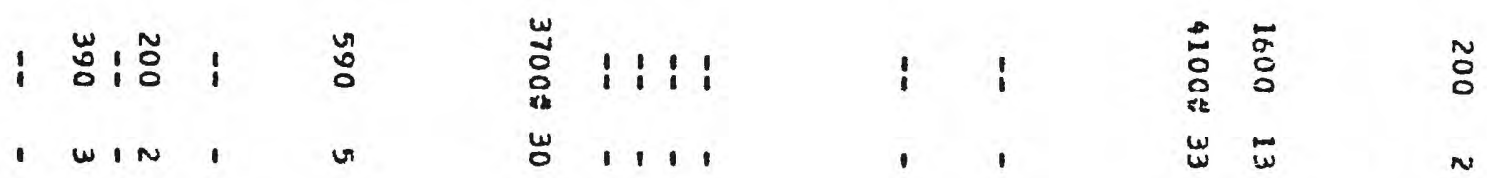



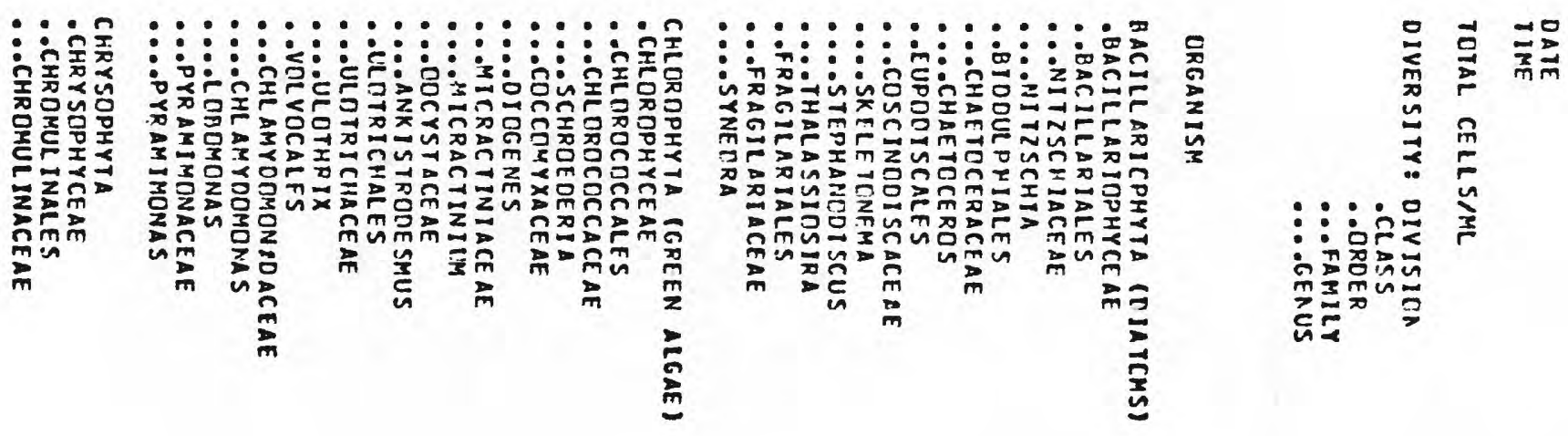

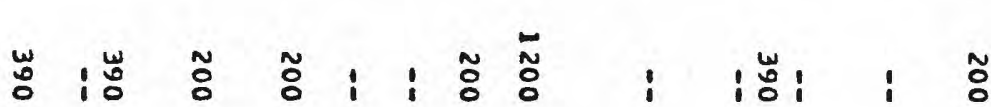
n In - . . . .

: 15

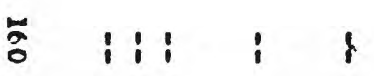

in $1,1,1$

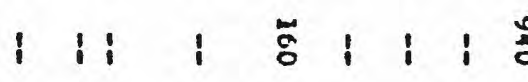

1, $11,1, \frac{1}{11}$

i $: \frac{a}{a} \quad 1$

罗:

15

- N

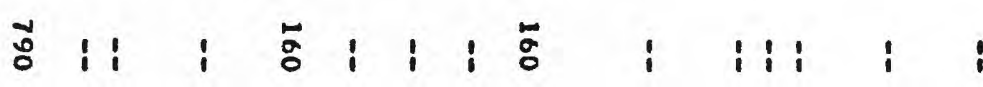
. 1

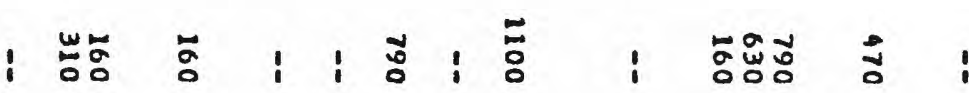
1 w- $-1,2$,

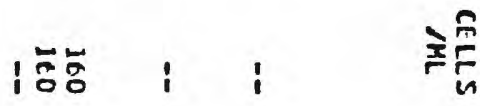

啋

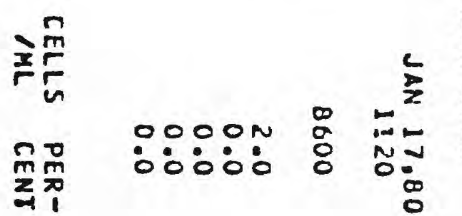
主每

产鱼

舟帝 空

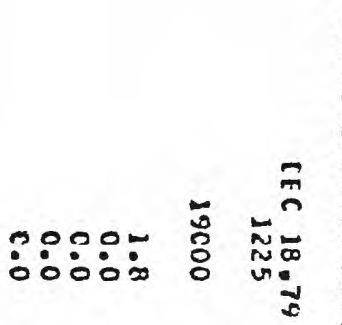

№:

每 a

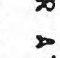

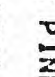
2 


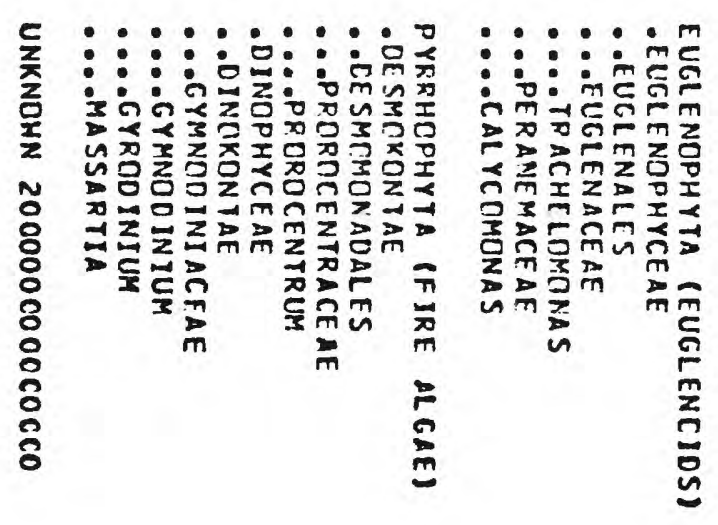

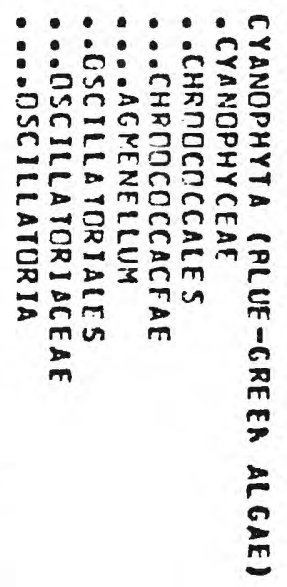

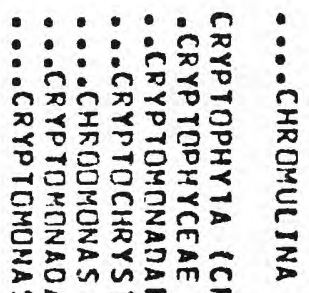

ion

i

m

$m$

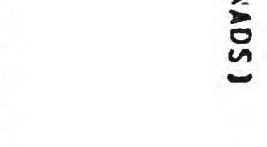

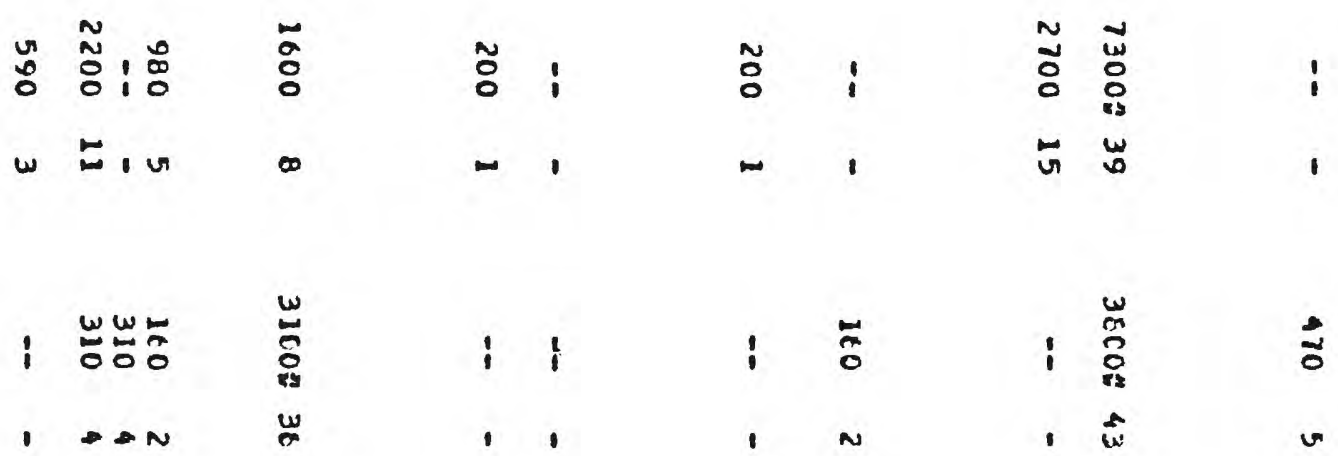

ڤ

Ð

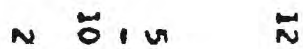

N 1

$\approx \omega$

ڤ

ถู !

$\begin{array}{ll}\omega & \omega \\ 0 & 0 \\ 0 & 0\end{array}$

ज

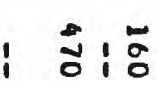

䫆

i 훙

$1 \stackrel{w}{w}$

- vin

N

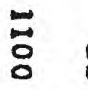

i $\stackrel{0}{0}$

i

$0 \Xi$,

0
0
0
0
0

- 

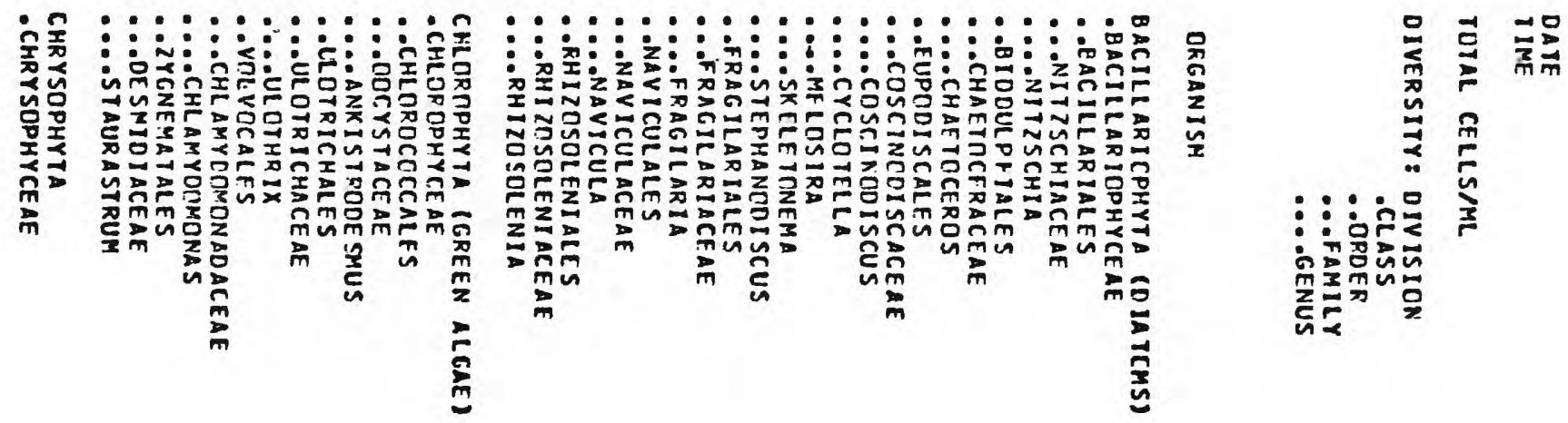

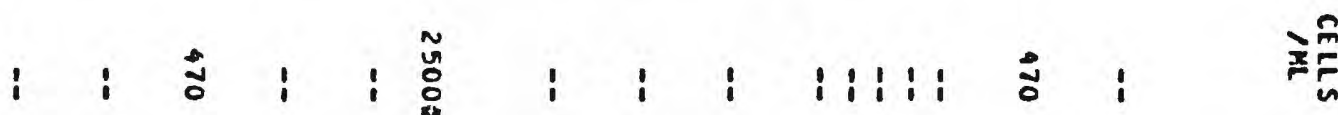

䙓

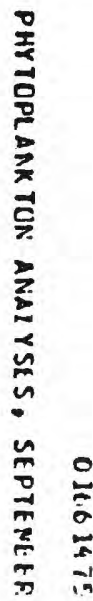

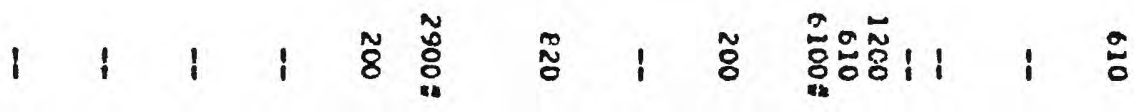
జwa, ,

紊察

$\sum_{i=1}^{\infty}$

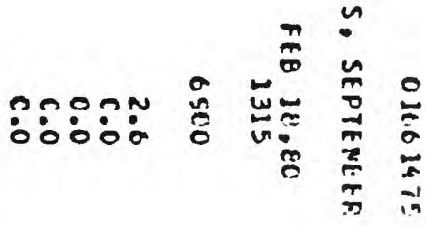

$\stackrel{\frac{F}{5}}{\mathrm{n}}$

率窗

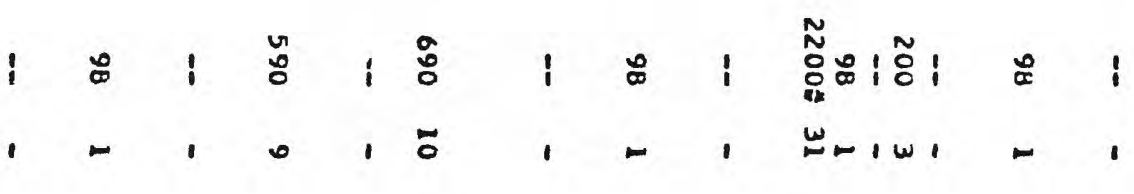

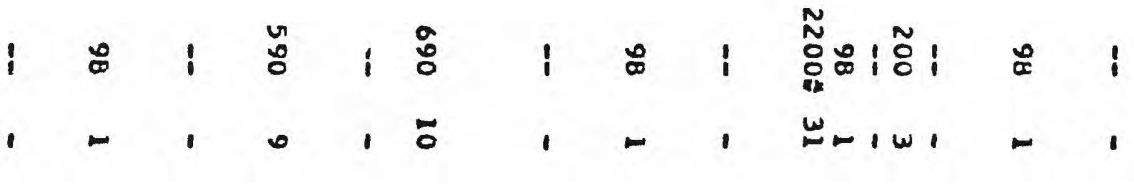

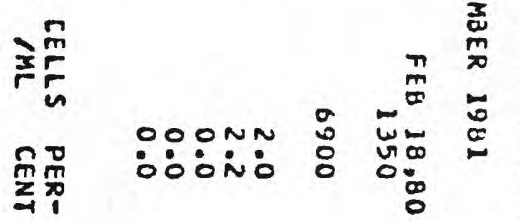

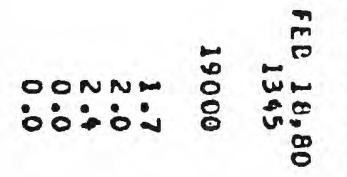

辛焦

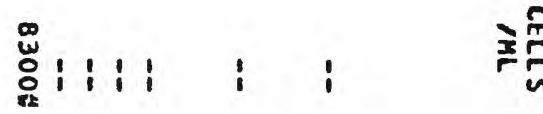

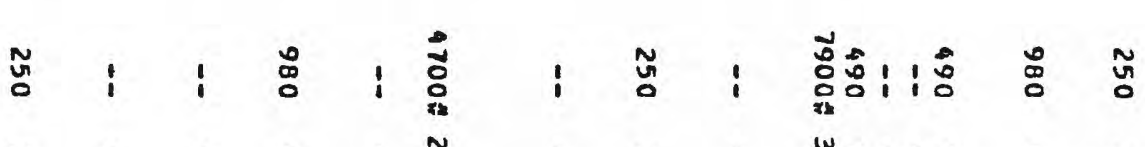

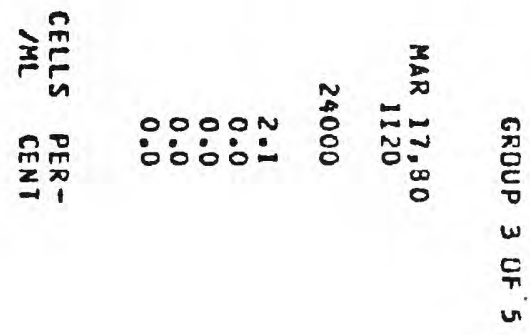




\section{UNITED STATES DEPARTMENT OF THE INTERIOR \\ DONALD PAUL HODEL, Secretary}

GEOLOGICAL SURVEY

Dallas L. Peck, Director

For additional information write to:

Chief Hydrologist U.S. Geological Survey Water Resources Division 430 National Center Reston, Virginia 22092
Copies of this report can be purchased from:

Open-File Services Western Distribution Branch U.S. Geological Survey Box 25425, Federal Center Denver, Colorado 80225 

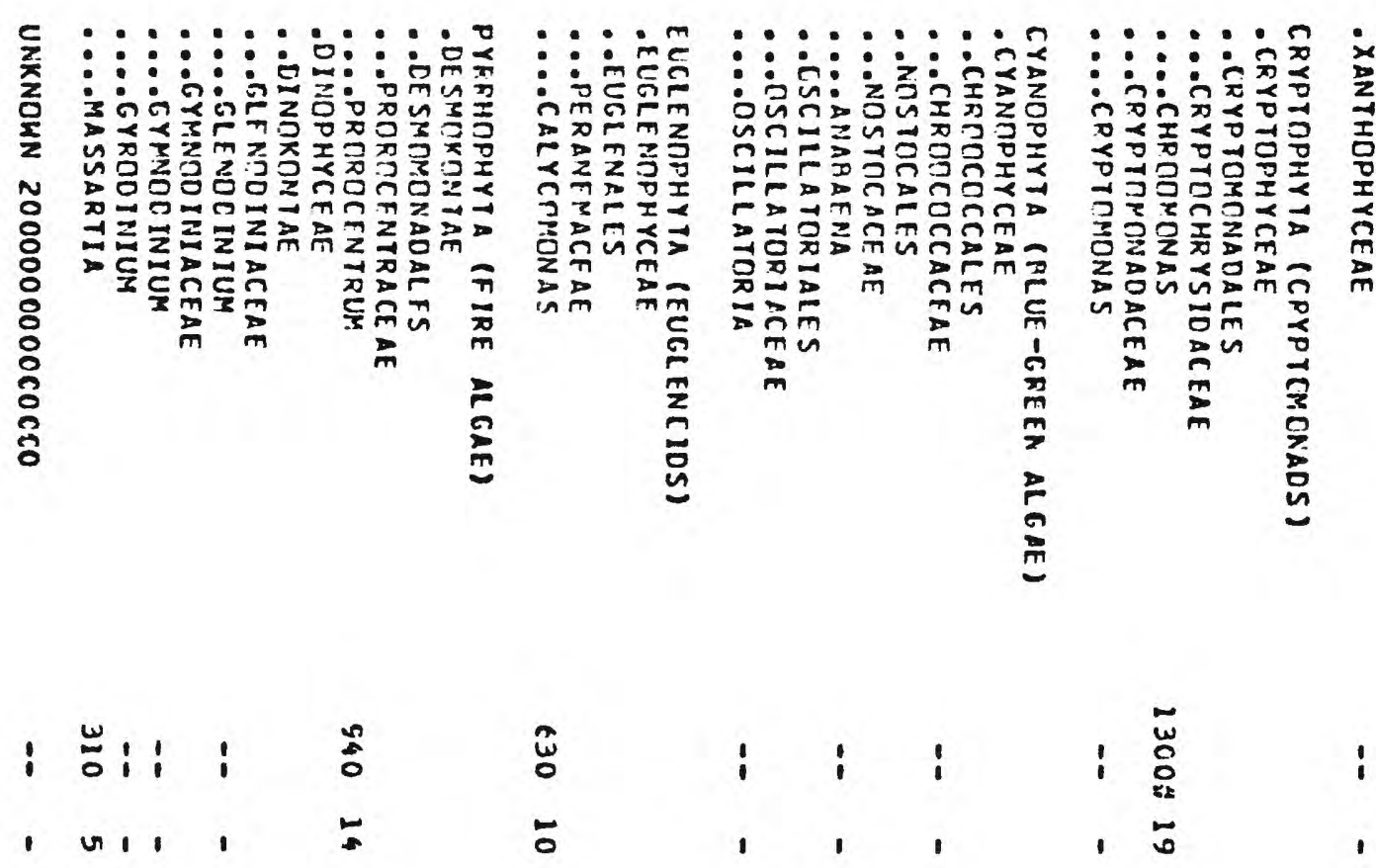

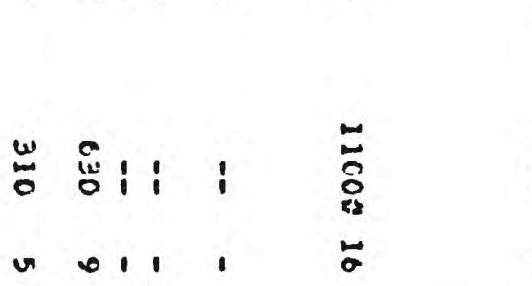

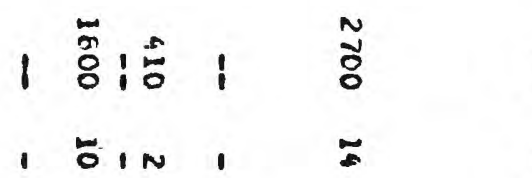

\begin{tabular}{|c|c|c|c|c|c|c|c|c|c|c|}
\hline & $\stackrel{n}{0}$ & $\tilde{0}$ & $\begin{array}{l}\tilde{N} \\
0 \\
0\end{array}$ & i & i & i & i & $\stackrel{8}{0}$ & $\tilde{\check{O}}$ & 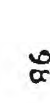 \\
\hline & $\approx 1-$ & - & $\approx$ & 1 & 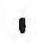 & ! & 1 & $\ddot{0}$ & $\omega$ & - \\
\hline
\end{tabular}

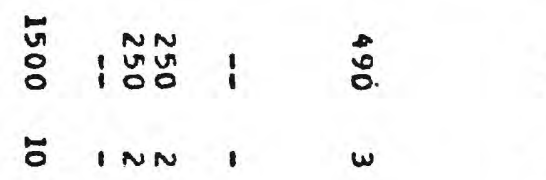

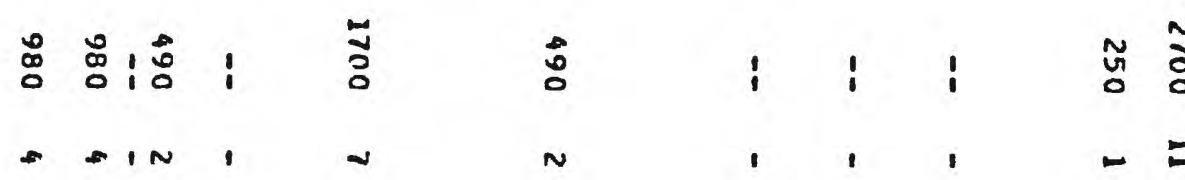




\section{References}

Butcher, R. W., 1959, An introductory account of the smallar algae of British coastal waters: Part I: Introduction and Chlorophyceae, Fishery Investigations, Ser. IV, p. 1-74.

Campbe11, P. H., 1973, Studies on brackish water phytoplankton: Sea Grant Publication UNC-SG-73-07, 361 p.

Cocke, E. C., 1967, The Myxophyceae of North Carolina: Edwards Bros., Ann Arbor, Michigan, 206 p.

Cohen, Ronald R. H., 1984, Phytoplankton dynamics, in Callender, E., and others (eds.), A water quality study of the tidal Potomac River and Estuary - an overview: U.S. Geol. Survey Water Supp. Pap. 2233. Drouet, F. and Daily P., 1956, Revision of the Coccoid Myxophyceae: Butler Univ. Botanical Studies, v. 12, p. 1-218. Eloranta, P., 1978, Effects of size of sample counted in phytoplankton analyses: Ann. Bot. Fennici, v. 15, p. 169-176.

Frontier, S., 1972, Calcul de l'erreur sur un comptage de zooplankton: J. Exp. Mar. Biol. Ecol., v. 8, no. 2, p. 121-132. Greeson, P. E., Ehlke, T. A., Irwin, G. A., Lium, B. W., and Slack, K. V., 1977, Methods for collection and analysis of aquatic biological and microbiological samples: U.S. Geol. Survey Techniques of Water-Resources Investigations, Book 5, Chapter 4, 1977, p. 91-112. Hasle, G. R., 1978, The inverted microscope method, in Sournia, A., (ed.), Phytoplankton Manual: Unesco, Paris, p. 88-96. Hasle, G. R., 1978, Diatoms, in Sournia, A., Phytoplankton Manual: Uresco, Paris, p. 136-142. 
Hobro, R. and Willen, E., 1977, Phytoplankton countings, Intercalibration results and recommendations for routine work, Int. Revue ges. Hydrobiol. v. 62 , no. 6, p. $805-811$.

Hubbert, E. M., 1965, Flagellates from brackish waters in the vicinity of Woods Hole, Massachusetts: Phycol., v. 1, p. 87-94.

Hustedt, F., 1930, Die Kieselalgen, in Rabenhorst, L., (ed.) Kryptogamenflora von Deutschland, Osterreich, und der Schweiz, Band VII., Part I, Academische Verlagsgesellschaft, Leipzig (Johnson Reprint Co.), New York, 920 p. Lund, J. W. G., Kilpling, C., LeCren, E. D., 1958, The inverted miscroscope method of estimating algal numbers, and the statistical basis of estimation by counting: Hydrobiologia, v. 11, no. 2, p. 143-170.

Patrick R. and Reimer, C. W., 1966, The Diatoms of the United States, v. 1, monograph no. 13: Academy of Natural Sciences of Philadelphia, Phila, Pa., $688 \mathrm{p}$.

Patrick, R. and Reimer, C. W., 1975, The Diatoms of the United States, v. 2, part 1, monograph n. 13: Academy of Natural Sciences of Philadelphia, Phila., Pa., 213 p.

Prescott, G. W., 1962, Algae of the western Great Lakes Area: Wm. C. Brown, Co., Dubuque, Iowa, 977 p.

Prescott, G. W., 1978, How to know the freshwater algae, 3rd ed.: Wm. C. Brown, Dubuque, Iowa, 293 p.

Sakshaug, E., 1980, Problems in the methodology of studying phytoplankton, in Morris, I., (ed.), The Physcological ecology of phytoplankton, p. 57-94. Blackwell, U. of Calif. Press, Berkeley. 
Saunders, R. P. and Glenn, D. A., 1969, Memories of the Hourglass Cruises, v. 1, part 3: Marine Research Laboratory, Dept. of Natural Resources, St. Petersburg, Florida, $119 \mathrm{p}$.

Utermoh1, H., 1958, Zur Verwollkommnung der quantitativen Phytoplankton Methodik: Mitt. int. ver. theor. angew. Limnol., v. 9, p. 1-38.

Venrick, E. L., 1978, How many cells to count? in Sournia, A., (ed.), Phytoplankton Manual: Unesco, Paris, p. 167-180.

Whitford, L. A. and Shumacher, G. J., 1973, A manual of fresh-water algae:

Sparks Press, Raleigh, N.C., 324 p.

Wood, R. D. and Lutes, J. 1968, Guide to the phytoplankton of Narragansett

Bay, Rhode Island: Univ. of Rhode Island Press, Kingston. 



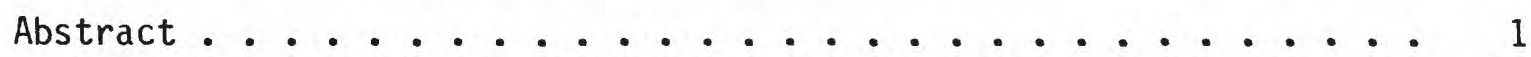

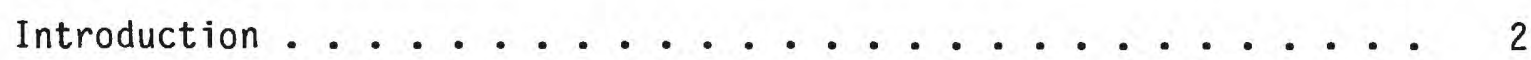

Methods....................... 6

Sampling stations. . . . . . . . . . . . . . 6

Methods for phytoplankton cell counts and identifications. . . . 6

Data presentation. . . . . . . . . . . . . 18

References ...................... 26

\section{ILLUSTRATIONS}

Figure 1. Map of the Potomac River and Estuary, Maryland. . . . 3

2a. Location of sampling stations in the fresh, tidal Potomac River, Maryland .......... 4

2b. Location of sampling stations in the transitionzone and estuary................. 5

3. Least squares regression of counts performed by Boulukos and Wapora to counts performed by Stoelzel . . 15

4. Natural logarithm regressions of counts performed by Boulukos and Wapora to counts performed by Stoelzel. . 16

\section{TABLES}

Table 1. A list of stations at which phytoplankton were sampled. The stations are marked on Figure 2.......... 7

2. Differences between classification schemes used by the Potomac Estuary Study Project and those of the U.S. Geological Survey Biological File......... 9

3. New identification numbers added to the U.S. Geological Survey Atlanta Water Quality Laboratories' list of

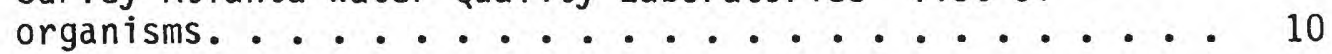

4. Phytoplankton genera listed by station, data, and time . 19 (Microfiche in pocket at back of report) 
For use of readers who prefer to use inch-pound system of units, the data may be converted to metric (International System) units by using the following factors:

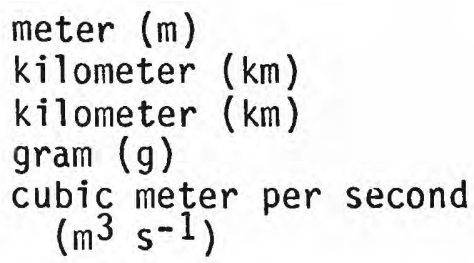
3.281
0.6214
0.5400
0.0022
35.31

foot (ft)

mile (mi)

nautical mile ( $\mathrm{nt} \mathrm{mi}$ ) pound ( $1 \mathrm{~b})$

cubic foot per second $\left(\mathrm{ft}^{3} / \mathrm{s}\right)$

\section{Concentration Conversions}

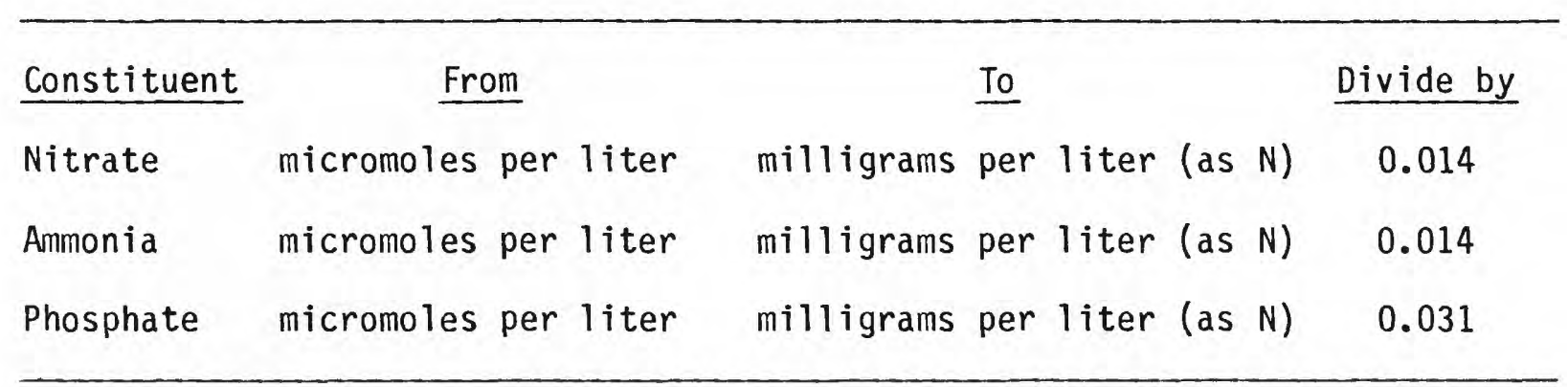


PHYTOPLANKTON ABUNDANCE AND GENERIC COMPOSITION DATA FOR POTOMAC RIVER AND ESTUARY, MARYLAND

\author{
By R. R. H. Cohen, S. O. Pollock, V. E. Stoelzel \\ and K. E. Boulukos
}

ABSTRACT

Phytoplankton of the Potomac River and Estuary were counted and identified to the generic level. Double-blind precision tests for an individual counter yielded a standard deviation that was $\neq 10$ percent of the mean. Differences between three counters exceeded $\neq 10$ percent, and a curve could be fit to calibration counts to yield correlation coefficients of 0.70 to 0.86 between counters. Counters identified the same genera that comprised the highest and second highest percentages of the population in 88 percent of the calibration samples. 


\section{INTRODUCTION}

Phytoplankton are a major component of aquatic ecosystems because they produce organic materials from inorganic nutrients using sunlight as an energy source. The microalgae that make up the phytoplankton are the primary energy source for most aquatic-ecosystems.

Counting phytoplankton cells is the oldest method of estimating biomass (Sakshaug, 1980). The method was used in the U.S. Geological Survey Potomac Study (Cohen, 1984) to help understand phytoplankton dynamics because cell enumeration and identification yields more information about aquatic-ecosystems than any other measure of phytoplankton biomass (Sakshaug, 1980). This report presents phytoplankton enumeration and generic identification data collected September 1979 through October 1981 as part of the Potomac River and Estuary study of the U.S. Geological Survey.

The tidal Potomac River, Maryland extends 187 kilometers $(\mathrm{km})$, from above Washington, D.C. at Chain Bridge to the Chesapeake Bay (fig. 1). Its tidal, fresh portion, approximately $62 \mathrm{~km}$ long, has a volume of $3.4 \times 10^{8} \mathrm{~m}^{3}$ and receives drainage from metropolitan Washington, D.C. as well as the nontidal Potomac River (fig. 2a). It has an average flow of $310 \mathrm{~m}^{3} \mathrm{sec}^{-1}$ and accepts approximately $1.4 \times 10^{6} \mathrm{~m}^{3}$ per day of waste water from municipal treatment facilities.

A zone of high, summer phytoplankton biomass extends from river kilometer 180 at Memorial Bridge to km 126 at Quantico (fig. 21), the approximate, late-summer location of the brackish water/freshwater interface.

Downstream from Quantico (km 125.6) to Morgantown (km 80.4) is the transition zone from fresh- to brackish-water (figs. 1 and $2 b$ ). The estuary, from Morgantown to Pt. Lookout ( $k m$ 6.5), is shown in figure $2 b$. 


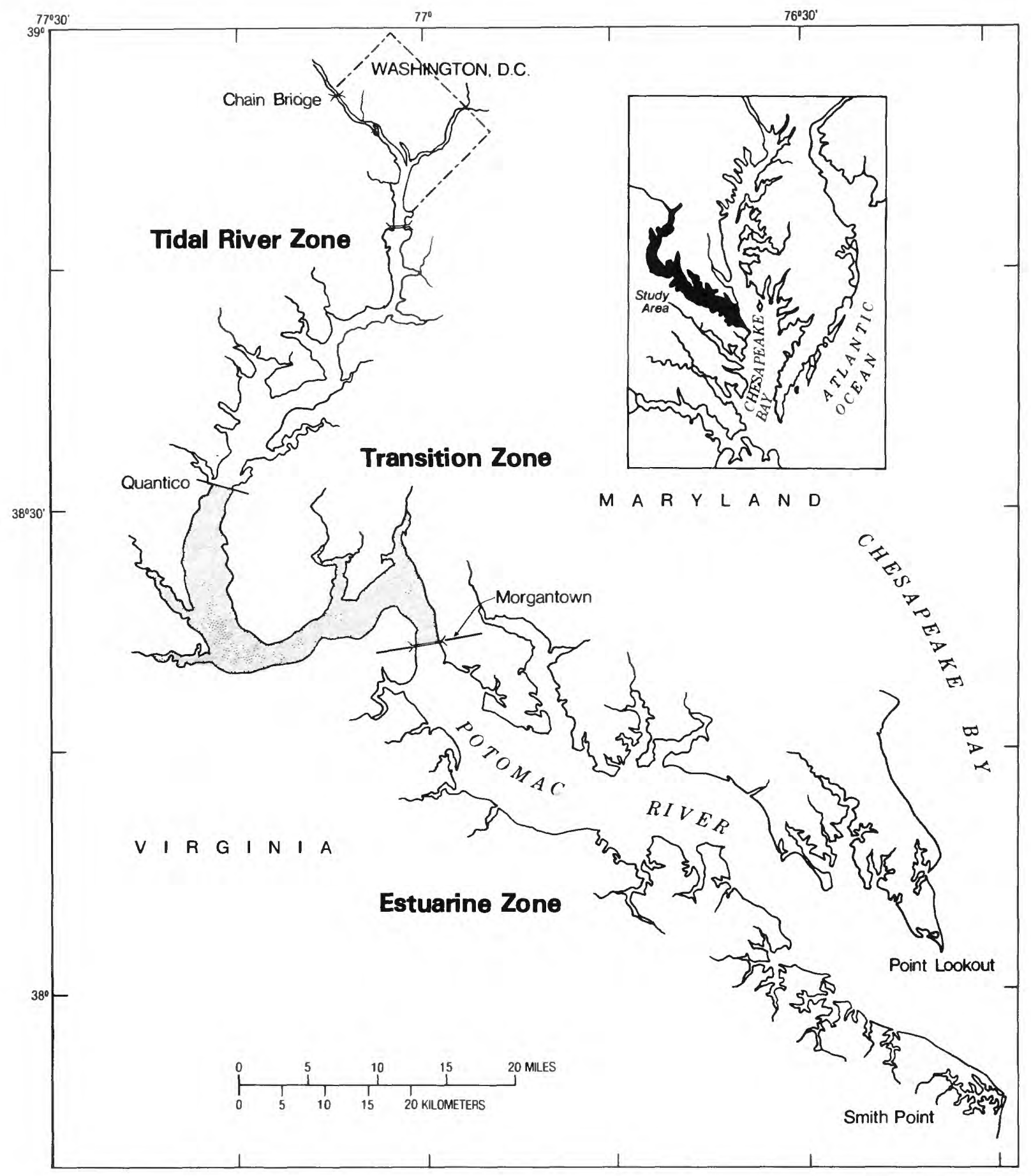

Figure 1.--Map of the Potomac River and Estuary, Maryland 


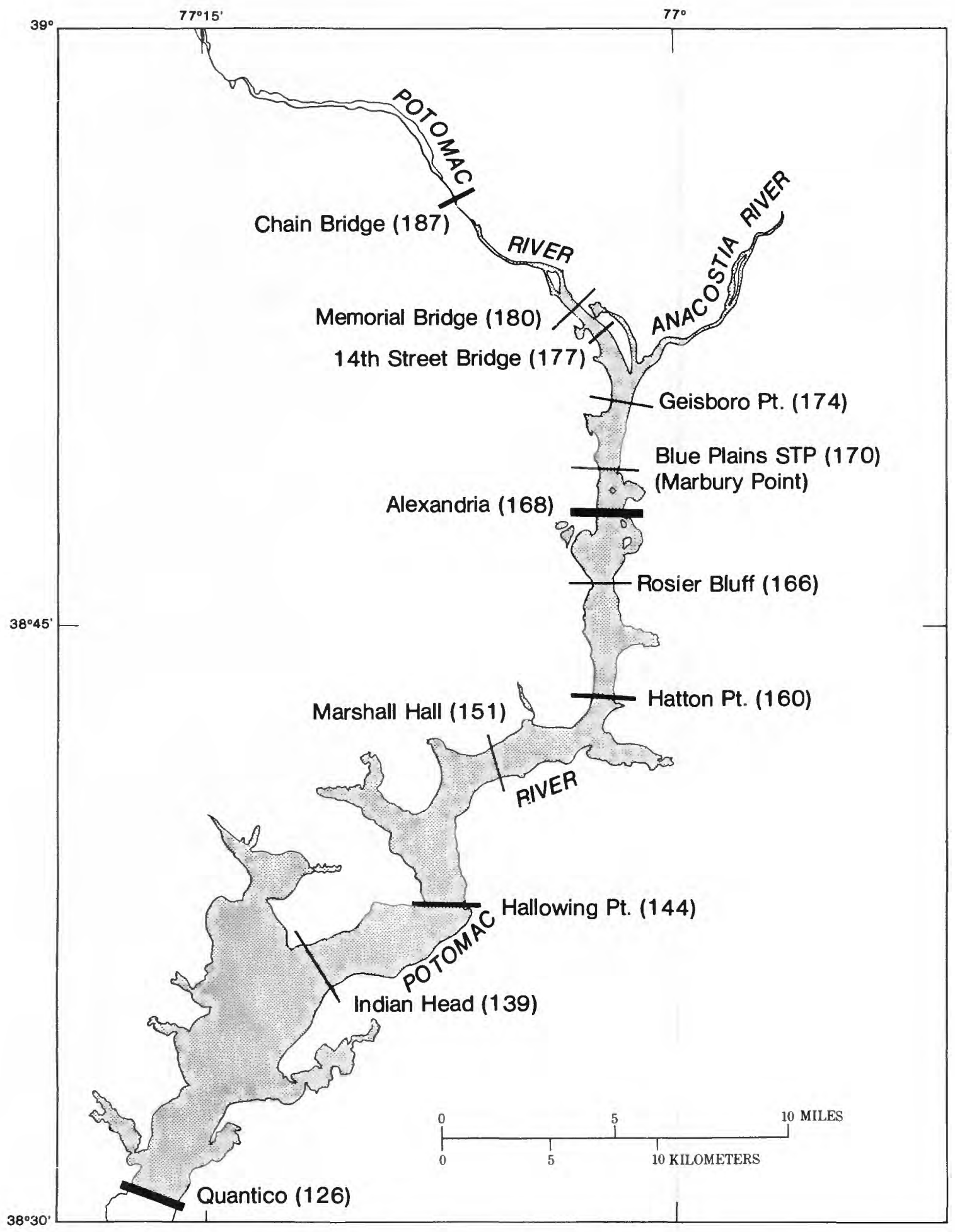

Figure 2a.--Location of sampling stations in the fresh, tidal Potomac River, Maryland. The Blue Plains Sewage Treatment Plant (STP) station is identical to Marbury Point. Sampling station distance, in kilometers from mouth of Potomac, are in parentheses. 